\title{
DARI PUISI MANTRA HINGGA PUISI ESAI SEBUAH LANSKAP PERPUISIAN INDONESIA
}

\author{
Awla Akbar Ilma \\ Program Studi Sastra Indonesia \\ Fakultas Sastra, Universitas Pemulang \\ J1. Surya Kencana No. 1, Pamulang, Tangerang Selatan \\ Email: dosen01664@unpam.ac.id
}

\begin{abstract}
This research specially addresses through a sociological perspective the existence of narrative poetry that lately rampant in Indonesia. Therefore, this research assumes that the existence of a literary work is closely link with the condition of the time. This research seeks to compare with the kinds of poetry before as traditional poerty, poetry of pujangga baru, mantera poetry, and Mbeling poetry both aesthetic characteristics and social conditions. Based on the research process, it is known that the narrative poerty has unique characteristics that are different from other types of poetry. It is known that narrative poetry is a real respond to assessment of poems that are considered difficult to understand. Therefore, this poetry tries to synergize with readers, making certain platforms, giving easy access to the meaning of the poetry. Thus sociological characteristics known as the effect of the conditions which always demanding the ease and speed. Such condition if drawn further was the effect of industrialization and technological pace.
\end{abstract}

Keywords: Sociology, Narrative Poetry, Reader, industrialization

\begin{abstract}
ABSTRAK
Tulisan ini secara khusus membahas melalui perspektif sosiologis keberadaan puisi esai yang akhir-akhir ini kemunculannya marak di Indonesia. Oleh karena itu, tulisan ini berasumsi bahwa keberadaan karya sastra memiliki kaitan erat dengan kondisi zamannya. Dalam menjelaskannya tulisan ini berusaha untuk membandingkan dengan jenis-jenis puisi sebelumnya seperti puisi tradisional, puisi era Pujangga Baru, puisi mantera, dan puisi Mbeling baik ciri estetiknya maupun kondisi sosialnya. Berdasarkan proses penelitian, diketahui bahwa puisi esai memiliki ciri yang unik yang berbeda dengan jenis puisi lainnya. Diketahui bahwa puisi esai merupakan respon nyata terhadap penilaian puisi yang dianggap sulit dipahami. Untuk itu, puisi ini mencoba untuk bersinergi dengan pembaca, membuat platform-platform tertentu, sehingga memberi kemudahan akses terhadap makna puisi. Ciri demikian secara sosiologis diketahui merupakan efek atas kondisi saat ini yang selalu menuntut kemudahan dan kecepatan. Kondisi demikian jika ditarik lebih jauh merupakan efek dari era industrialisasi dan kecepatan teknologi.
\end{abstract}

Kata Kunci: Sosiologi, Puisi Esai, Pembaca, Industrialisasi

\section{PENGANTAR}

Sejarah puisi Indonesia sangatlah panjang. Jika ditengok ke belakang sebelum Sastra Indonesia Modern lahir akan ditemui puisi-puisi dalam bentuk tembang, misalnya tembang 
Jawa, syair-syair masyarakat Arab Badui yang mengisahkan kemenangan dan kekalahan perang antar suku, sajak-sajak bernama bini yang dibawakan oleh para manaholo (penyair tradisional masyarakat Rote) dan berisi peristiwa-peristiwa penting yang dilakukan oleh para tetua adat di masa silam.Melalui puisinya, para penyair tersebut memposisikan dirinya sebagai aktor yang mengendalikan sejarah masyarakat berdasarkan sumber mitis yang diacu, karena terhadap acuan mitis itulah kehidupan masyarakat sehari-hari diorientasikan sekaligus menemukan status historisnya.

Masa itu, kapitalisme dan ilmu pengetahuan belum melembaga dan otonomi individu belum menguat seiring goyahnya kepemilikan individu dalam sistem ekonomi masyarakat sehingga peran penyair sangat penting dalam menjaga keseimbangan sosial, yang oleh orang Yunani Kuno disebut sebagai kosmos. Pentingnya peran para penyair tersebut terkait dengan kenyataan bahwa puisi (dalam bentuknya yang paling umum, yaitu sebagai produk bahasa berdasarkan permainan irama) masih merupakan bentuk pengucapan yang paling mewakili karakter kosmis dan transenden dari mitos dan ideologi masyarakat pramodern. Usaha pengkosmisan dilakukan melalui permainan harmoni dalam irama puisi, dan usaha transendensi dicapai melalui repetisi yang mengantarkan pengucap dan pendengarnya menempuh tingkatantingkatan intensi hingga mendekati bentuk penghayatan yang paling menyerupai tatanan ideal alam semesta, sesuai mitos atau ideologi yang diacu (Kamandobat, 2013).

Senada dengan acuan itu, Michael Foucault melalui The Order of Think mengemukakan bahwa episteme pada zaman renaisanse adalah keserupaan antara tanda dengan yang ditandai. Oleh karena itu, alam adalah meterial tanda yang diinterpretasi, sehingga pengetahuan tentangnya adalah tanda yang serupa. Keserupaan inilah yang mengakibatkan pemahaman bahwa pengetahuan sangat dekat dengan alam. Dengan keberadaan demikian, posisi para penyair kemudian dimaknai sebagai pewarta agung yang mengisi makna alam dunia secara penuh hingga ia sering dianggap suci.

Muncul perubahan yang cukup signifikan ketika lahir puisi modern Indonesia yang ditandai dengan muncunya puisi Muhammad Yamin dengan judul Tanah Air. Puisi ini secara tegas menggunakan Bahasa Indonesia sebagai mediumnya dan lebih sebagai respons terhadap karya sastra Melayu Lama. Secara tekstual puisi ini menyimpang dari konvensi puisi lama, terutama mengedepankan perasaan individu dan mengkonversikan beberapa bentuk liris antara pantun dan syair.

Keberadaan puisi dengan bentuk demikian ternyata semakin kokoh dengan munculnya puisi-puisi Pujangga Baru hingga kemudian mencapai keutuhannya lewat kehadiran puisi "Aku" karya Chairil Anwar di era 45. Sebagai tonggak dari puisi yang "benar-benar modern" puisi "Aku" semakin mengukuhkan posisi individu sebagai sepenuhnya subjek dihadapan objek. Sehingga tampak dari gagasan maupun aspek tekstualnya, puisi ini memiliki ciri kebebasan penuh, menonjolkan "keakuan", beraliran realisme dan sebagainya.

Ditinjau dari aspek sosiologis perubahan ini terkait dengan gencarnya kapitalisme yang telah mencabut hak milik kolektif menjadi milik individu. Kondisi demikian menimbulkan segregasi institusi keagamaan, kekerabatan dan adat, yang diikuti pula dengan memudarnya nilai, ritual dan upacara. Oleh karenanya, puisi lebih mengedepan sebagai interpretasi individu terhadap alam, sehingga bentuk puisi lebih sebagai modus penghadiran individu penyair ke dalam bahasa.

Perbedaan konteks dan pengalaman, serta respon seniman terhadap karya-karya sebelumnya menjadi faktor penentu lahirnya suatu karya baru. Setelah munculnya puisi "Aku", puisi Indonesia pun terus mengalami perubahan dan dinamika. Lahirnya puisi mantra Sutardji Chalsum Bachri, puisi Mbeling Remy Sylado hingga yang santer terdengar puisi esai Dannya JA merupakan wujud dari perubahan-perubahan tersebut. Perubahan-perubahan 
tersebut sebagaimana dipaparkan di atas sangat terkait dengan konteks dan jiwa zaman yang melingkupinya.

Merujuk pernyataan tersebut, Wellek dan Warren (1956:84) mengemukakan pendekatan sastra berdasarkan lingkup sosiologi, dimana sastra dapat dipandang sebagai produk masyarakat sehingga mencermikan masyarakatnya. Alan Swingewoon pun mengemukakan bahwa sastra $A t$ the present time it's possible to characterize two broad approaches to a sociology of literature. The most popular perspective adopts the documentary aspect of literature, arguing that it provides a mirror to the age (Swingewood, 1971:13).

\section{PUISI MANTRA SEBAGAI SATU GENRE PROBLEMATIS}

Dalam perkembangan puisi Indonesia, munculnya puisi "mantra" tahun 1970 merupakan satu momen yang unik. Kesadaran Sutardji dalam menggali akar kebudayaan dan keanekaan estetis membawa pada rumusan kredo puisi "membebaskan kata dari makna." Ciri estetika yang ia kembangkan ialah menggunakan kata-kata faerah secara mencolok, mempergunakan asosiasi bunyi, gaya penulisan yang prosais, puisi lugu yang menggunakan ide secara polos, serta menggunakan gambaran dan pengucapan tak langsung.

Secara menyeluruh, puisi Sutardji hadir di antara ketegangan tradisionalitas, modernitas, dan posmodernitas. Puisi-puisi Sutardji menjadi asumsi atas kesadaran bahasa dan olahan estetik untuk membuka kemungkinan-kemungkinan struktur dan sistem makna. Secara historis, munculnya gaya demikian oleh kritikus disebut sebagai gaya absurdis. Gaya ini muncul lebih karena pemberontakannya terhadap gaya realis yang sejalan dengan munculnya era modernisme. Sapardi Djoko Damono (2007:9), mengemukakan bahwa modernisme menciptakan distansi dalam kenyataan, oleh karena itu muncul gaya absurdis dengan mengedepankan bentuk daripada isi, dan mengedepankan avant-gardisme, suatu upaya terusmenerus untuk melakukan pembaharuan, eksperimentasi dan terobosan melalui teknik, bentuk, cara pandang, dan gaya dalam mengeksplorasi seni. Oleh karena itu, kehadiran kredo puisi mantra bukan lagi dipahami sebagai upaya mengembalikan kedudukan bahasa kembali dalam konsep masyarakat "pramodern" yang mempercayai kedudukan simetris antara kosmis dengan tanda. Akan tetapi, lebih realistis dipahami sebagai strategi demi melawan gairah realisme serta modernisme di atas. Ia juga tampak lebih memberi ruang kebebasan bereksperimen dalam penggunaan bahasa dan bentuk, seperti yang dikatakan Ajip Rosidi (1977:6), bahwa mereka seakan-akan menjajaki sampai batas kemungkinan Bahasa Indonesia sebagai alat pengucapan sastra sehingga antara prosa dan puisi pun kian tidak jelas.

Di sisi lain, kehadiran gaya absurdisme ini tak bisa dilepaskan dengan konteks sosiologisnya. Era 70-an merupakan era dimana rezim Orde Baru sangat mendominsi dengan kekuatan militernya. Berdasarkan alasan ini, absurdisme dipahami oleh segelintir sastrawan lebih sebagai bentuk, tidak hanya membebaskan kata dengan makna, melainkan juga menunjukkan ketertundukkan terhadap rezim penguasa. Perlu disinggung, tahun 1970 kegiatan sastra diwarnai dengan aturan-aturan yang ketat. Karya yang bersifat provokasi, mengancam, melecehkan, menyinggung dan merugikan akan ditindaklanjuti dengan segera oleh penguasa. Misalnya saja, Majalah Djaja yang berhenti terbit sebab memuat masalah-masalah budaya dan kesenian Indonesia. Oleh karenanya, gaya absurditas di era tersebut dimaknai sebagai cara melarikan diri dari segala konfrontasi, cenderung membangun dunia sendiri, melepaskan diri dari frame masyarakat untuk bebas dari tekanan dan kontrol kekuasaan politik (Wahid, 2000:44).

Meski demikian, selang beberapa tahun setelah hits puisi mantra lahirlah puisi-puisi Mbeling prakarsa dari Remy Sylado. Puisi ini merupakan tanggapan atas kedudukan puisi yang 
ditempatkan begitu tinggi sebagaimana naluri estetika dari puisi Mantera. Bahkan Remy Sylado menegaskan bahwa puisi harus diletakkan di telapak kaki. Orang tidak perlu terlalu serius dalam soal puisi. Menulis sajak tidak perlu dipandang sebagai pekerjaan yang sukar, semua hal dapat disajakkan. Yang terpenting adalah kejujuran, keterusterangan, dan kesertamertaan.

Kehadiran puisi Mbeling jelas merupakan antitesis dari keberadaan puisi mantra. Hal ini sekaligus menandai munculnya kesadaran akan kebenaran bentuk karya yang bersifat relatif dan heterogen. Menyinggung sebuah terminologi, perdebatan demikian identik dengan sifat dari era posmodernisme. Sejalan dengan pendapat itu, tahun 80-an diakui memang era dimana kesadaran atas posmodernisme mulai berkembang. Hal itu ditandai dengan munculnya teknologi media massa sehingga meleburkan batas jarak waktu, ras, kelas, ideologi atau faktor lain yang menghambat komunikasi dan bertukarnya pikiran (Pujiharto, 2010:106). Kondisi ini ditunjangpula dengan muncul dan maraknya teori-teori posmodernisme di perguruanperguruan tinggi Indonesia.

Perdebatan mengenai bentuk karya sastra tersebut kemudian mencapai titik puncak dengan munculnya perdebatan sastra kontekstual pada tahun 1984. Gerakan ini merupakan usaha mengembalikan sastra ke dalam lingkungan sosial konkrit, mencoba membuatnya menjadi sebuah kekuatan sosial yang nyata dalam menghadapi industrialisasi, tidak hanya menjadi bangunan dunia dan kekuatan subjektif semata (Faruk, 2001:120). Terkait dengan kondisi rezim Orde Baru yang kian berkuasa, perdebatan ini tentunya menjadi satu perhatian khusus mengenai bagaimana posisi sastra, keberpihakan sastra terhadap masyarakat dihadapan politik (Heryanto, 1985:83).

Perdebatan ini seakan menjadi titik kesadaran baru bahwa sastra harus berpihak, "kontekstual" dengan masyarakatnya. Terbukti dalam tahun-tahun setelah itu, muncul perubahan yang cukup ekstrim untuk menentang pihak penguasa. Hal itu tampak dalam puisi Wiji Thukul di tahun 1994 yang kemudian menjadi sajak wajib dalam aksi-aksi massa, seperti puisi Peringatan, Sajak Suara, dan Bunga dan Tembok. Ciri bahasa dari puisi ini sangat vulgar dan tajam mengkritik pemerintah Orde Baru.

\section{KEHADIRAN PUISI ESAI}

Pada tahun 2012 muncul sebuah karya sastra yang tidak lazim. Jika sebelumnya muncul karya mantera kontemporer, pada tahun 2012 muncul karya puisi esai. Adalah Denny JA, yang memperkenalkan bentuk puisi ini dalam kumpulan puisinya, Atas Nama Cinta. Puisi ini merupakan jawaban atas riset yang dilakukan oleh Lingkaran Survei Indonesia tahun 2011 (Denny JA, Jurnal Sajak, nomor 3, 2012:69) yang menunjukkan bahwa puisi merupakan sesuatu yang asing di masyarakat. Secara eksplisit, dalam riset itu dikemukakan bahwa bahasa puisi terlalu njlimet, mereka yang berpendidikan tinggi sekalipun tidak mampu memahaminya.

Puisi esai hadir menggunakan platform ketat untuk menjembatani persoalan itu,antara lain pertama, harus mengeksplorasi sisi batin individu yang sedang berada dalam sebuah konflik sosial. Kedua, menggunakan bahasa yang mudah dipahami. Ketiga, puisi esai adalah fiksi. Boleh memotret tokoh nyata yang hidup dalam sejarah, namun diperkaya dengan aneka tokoh fiktif dan dramatisasi. Yang terpenting adalah renungan dan kandungan moral yang disampaikan lewat kisah, bukan semata potret akurat sebuah sejarah. Keempat, puisi esai tidak hanya lahir dari imajinasi penyair, tetapi hasil riset minimal realitas sosial. Kelima, puisi berbabak dan panjang (Rahman, 2013:35).Sementara itu, puisi esai juga dilengkapi dengan catatan kaki. Fungsi catatan kaki adalah mempermudah memahami makna yang disampaikan,serta memberikan pengetahuan dan wawasan baru yang bersifat konteksualdenganmakna puisi. 


\section{PUISI ESAI DAN DAN KONTEKS SOSIOLOGIS}

D. Zawawi Imron dalam pengantarnya di buku kumpulan puisi esai Manusia Gerobak mengatakan bahwa ketika sastra dituduh terpencil, atau dituduh megah bermukim di menara gading, kumpulan puisi esai Manusia Gerobak masih punya kepercayaan bahwa duka kemanusiaan bisa menemukan kendaraan ungkap lewat puisi esai seperti yang ditulisnya (Imron, 2013:44). Pernyataan Zawawi tersebut serta misi yang diangkat Danny JA sebagai penggagas sebenarnya membawa kembali pada kecenderungan permasalahan klasik tentang perdebatan sastra kontekstual sebagaimana telah disinggung dalam subbab 3.

Kehadiran puisi esai menjadi semacam gerak searah dengan semangat perdebatan sastra kontekstual terutama dalam mengkritisi generasi yang terus-menerus membangun dunia seni sebagai bangunan dunia subjektif batin seniman sebagaimana dalam puisi-puisi Sutardji. Oleh karena itu, gagasan puisi esai sejalan pula dengan gagasan dan semangat dari cerpen-cerpen Seno Gumira yang berbau jurnalistik maupun puisi Wiji Thukul di era 90-an.

Konsep sastra kontekstual sering dikatakan Arief Budiman merupakan misi untuk melakukan pembelaan terhadap rakyat lewat sastra. Kedudukan sastra tidak bisa lepas dari politik, dalam artian aneka siasat dan tingkah laku dalam memperebutkan atau mempertahankan kekuatan sosial. Kedudukan sastra bagi paham kontekstualitas adalah bagaimana karya sastra dipahami secara kontekstual dengan audience, estetika, pesan, terkait pula dengan makna dari karya sastra yang tidak bisa terlepas dari ruang dan waktu. Sejalan dengan gagasan itu, puisi esai pun berupaya untuk mendekatkan fiksi dengan fakta melalui kehadiran aturan ketat yang mengharuskan penyertaan catatan kaki. Bahkan dalam pandangan puisi esai, hidup secara penuh dengan masyarakat Indonesia harus dibuktikan dengan keterlibatannya dengan persoalanpersoalan besar bangsa, terutama masalah kemiskinan dan ketidakadilan, oleh karenanya karya-karya yang representatif adalah karya-karya yang menyuarakan suara demikian. Para penyair pun bagi puisi esai merupakan seorang yang terlibat dengan masyarakatnya, yang mau menyatakan sesuatu yang dianggap penting.

Kelima puisi esai Denny JA tampak dengan tegas berpihak pada para korban diskriminasi, dan seakan menitipkan protes, simpati, dan tekadnya melawan arus ketidakadilan melalui suara para aktor liris, dan merasa memikul tanggung jawab untuk melakukan advokasi terhadap mereka yang tidak diperlakukan sama dan setara di depan hukum. Sajak Minah Tetap di Pancung misalnya, menceritakan Minah seorang TKW yang bekerja di Timur Tengah. Sebagai TKW ia diperkosa oleh tuannya, paspornya ditahan, gajinya tidak dibayar, dan hanya diberi beberapa uang real setiap habis diperkosa. Dia ingin mengirim uang untuk anaknya yang belum bersekolah karena tak ada biaya. Hatinya pun berontak, ia tak mau memberi keluarganya uang haram hadiah perkosaan. Ia akhirnya menyobek uang itu tanpa sisa. Dalampercobaan perkosaan terakhir lewat ancaman pisau oleh tuan rumah, dia berhasil merebut pisau itu dan menghunjamkannya ke perut sang pemerkosa dan tewas seketika. Minah akhirnya dihukummati.

\footnotetext{
"Aminah namaku/ Minah panggilanku, TKW asal Indonesia/Kerja di Saudi Arabial Sebagai pembantu rumah tangga/ Kini aku sudah mati/ Algojo memenggal leherku/ Karena telah membunuh majikan/ Yang berulang kali memperkosaku/ Dan menyiksa jiwaku..."
}

Kutipan di atas menunjukkan bahwa persoalan sosial yang aktual terjadi di masyarakat, dieksplorasi dengan serius oleh penyair. Bahkan melalui catatan-catatan kakinya ditunjukkan fakta-fakta yang mendukung kisah yang dihadirkan puisi tersebut. Berikut kutipan salah satu catatan kakinya: 
"Siksaan seperti yang dialami Aminah telah menjadi cerita umum di kalangan para TKW. Sepanjang tahun 2010, sebanyak 1.075 TKW Indonesia disiksa majikannya. Tak jarang, penyiksaan tersebut berujung kematian. Migrant Care mencatat dari tahun 2007 hingga 2011 ada 10 orang TKW di berbagai negara yang meninggal karena disiksa majikannya. "

Tampak jelas bahwa pengarang mengeksplorasi fakta untuk dibuat cerita dalam bentuk puisi. Dengan demikian, hal-hal yang menjadi kekuatan puisi esai adalah proses kreatif dari penyair dalam mengolah data sehingga kondisi sosial yang sering terjadi dan terdengar di masyarakat menjadi semakin terasa baru dan menyentuh jiwa pembaca.

Jiwa zaman tentu menjadi pengaruh utama lahirnya puisi demikian. Meskipun semangat yang dibawanya identik dengan puisi Wiji Thukul dengan mengangkat problem kontekstual, namun kehadiran puisi ini tetap memiliki ciri unik berdasarkan konteks yang mempengaruhinya. Sebagaimana dikemukakan di atas, puisi ini merupakan jawaban atas hasil survei yang menyebutkan bahwa puisi sulit untuk dimengerti. Oleh karena itu, puisi esai hadir dengan kemudahan-kemudahan untuk dimengerti lewat bahasa yang dipakai serta kehadiran catatan kaki. Dengan ciri demikian, pembaca disuguhi secara detail maksud maupun latar kisah yang diangkat. Hal ini serasa merancukan pengertian puisi yang multiinterpretasi.

Dengan kriteria-kriteria semacam ini tampak bahwa puisi esai benar-benar mempertimbangkan penuh aspek audience. Kecenderungan sikap dan tindakan masyarakat masa kini coba dipahami betul oleh penyair puisi esai. Karakteristik masyarakat sekarang adalah masyarakat post-industrial atau masyarakat konsumen (Kristanto, 2002:9). Kehadiran teknologi, ketergantungan terhadap internet, memunculkan generasi serba cepat. Dalam situasi ini hasil lebih dipentingkan ketimbang proses, saking cepatnya, muncul anekdot "berpikir adalah sesuatu yang harus dihindari". Oleh karena itu, puisi esai pun mengemukakan gagasangagasan kemudahan dalam mengakses makna, terutama dengan menghadiran catatan-catatan kaki. Dengan sikap demikian, gagasan otentisitas, konsep mengenai ekspresi puisi yang berangkat dari dalam diri sendiri sejujur-jujurnya, dari gejolak perasaan individu yang paling murni, tampak diganti dengan perhitungan-perhitungan. Sebagaimana dalam karya sastra populer, sejak awal puisi esai telah bersinergi dengan pembaca. Ia memperhitungkan selera pembaca, bersifat pretensius, dipaket untuk tujuan komersial yang dianggap eksploitatif.

Sementara itu, basis utama tema yang harus ditampilkan puisi esai tentang kemiskinan dan keadilan menunjukkan adanya kontekstualitas dengan persoalan besar bangsa. Akan tetapi, tidak seperti puisi Wiji Tukul, puisi ini lebih bersikap sopan, ia tidak mengajak pembaca untuk memarah-marahi pemerintah secara provokatif, melainkan mengajak menyelami persoalan dengan penuh perasaan, dalam istilah Denny JA didramatisasi, mengangkat renungan dan kandungan moral.

Sikap puisi esai demikian merupakan satu bentuk diskusi dengan kecenderungan masyarakat kekinian. Seiring runtuhnya rezim Orde Baru dan terbukanya demokrasi, munculah peningkatan besar-besaran jumlah kelas menengah di Indonesia. Berdasarkan hasil penelitian Litbang Kompas (Edisi 8 Juni 2012) jumlah kelas menengah di Indonesia telah naik drastis, dari hanya sekitar 80 Juta (37,7\%) penduduk menjadi 130 juta pada 2011 (56,5\%). Sikap dari kelas menengah indonesia ini justru digerakkan untuk menjadi individu yang konservatif, pragmatis, oportunis, konsumtif, dan intoleran (Aziz, 2013:4). Artinya generasi ini adalah generasi konsumtif, malas untuk menyuarakan suaranya, cenderung apatis, dan lebih mementingkan diri sendiri dengan memilih jalur aman. Hal ini berbeda dengan konteks masyarakat ketika lahir puisi Wiji Tukul. Gerah dengan penguasa menjadi satu pemahaman kolektif untuk terjadinya pergantian penguasa. Dengan demikian, hanya dalam batas-batas tertentusaja peran kontekstual puisi esai ini, sesuai dengan pernyataan Zawawi, puisi ini patut 
dihargai setidaknya telah mengangkat duka kemanusiaan secara reflektif di tengah masyarakat yang apatis terhadap kondisi, dan bahkan menganggap puisi jauh di atas menara.

\section{KESIMPULAN}

Memahami karya sastra, memahami pulacara berpikir dan jiwa zaman suatu masyarakatnya. Melalui cara baca sosiologisdalam membaca puisi Indonesia, dipahami bahwa era 80-an merupakan era dimana sikap pluralisme, heterogenitas kekuasaan mulai muncul. Era ini identik dengan apa yang dinamakan dengan kesadaran posmodernisme. Kehadiran dua jenis puisi yang berbeda antara puisi mantra dan puisi Mbeling menunjukkan kecenderungan tersebut. Perbedaan pendapat dalam memahami puisi, bahkan karya sastra di era 1980, sempat memuncak dengan hadirnya perdebatan sastra kontekstual. Kontekstualisasi sastra dalam perkembangannya mendapat respon positif lewat puisi Wiji Tukul terkait sikap penguasa Orde Baru yang menindas, militeristik, dan berkuasa.

Kini di era demokrasi muncul kembali isu, kesadaran, dan pendapat yang mendudukkan puisi berdasarkan konteks masyarakatnya. Puisi esai dengan sederet platformnya, menempatkan dirinya berada di antara fakta dan fiksi, hingga pemaparan fiksi tidaklah memiliki makna yang ambigu.Meski demikian, fakta yang dihadirkan berbeda dengan tujuan konteksualisasi yang ada di era baik Lekra maupun era 90 -an. Karakteristik masyarakat sekarang yang bersifat postindustrial, konsumetif, dengan semakin tergantung dengan teknologi memunculkan generasi serba cepat. Munculnya platform yang memudahkan penerimaan puisi esaimerupakan efek atasnya. Dengan demikian, sejak awal puisi esai telah bersinergi dengan selera pembaca sehingga identik dengan karya sastra populer yang memiliki maksud komersial. Meski demikian, sifat puisi ini tidak sepenuhnya negatif. Hadirnya tema utama puisi esai berupa problem kemanusiaan tentu efektif jika dipaparkan dengan mudah sehingga akan banyak pihak yang tersentuh. Akan tetapi, ciri puisi esai demikian pun memiliki efek samping: mudah dan cepat dipahami, sikap masyarakat yang juga cepat dan tak memahami esensi membuat refleksi yang ingin disampaikan puisipun hanya sekadar menjadi angin lalu: cepat dibaca, mudah berlalu, dan dilupakan. Entahlah.

\section{DAFTAR PUSTAKA}

Aziz, Umar Abdul. 2013. "Masyarakat Kelas Menengah Indonesia: Terkurung dalam Paradigma Kapitalisme Pinggiran". https://www.academia.edu.

Damono, Sapardi. Djoko dkk. 2007. Absurdisme Dalam Sastra Indonesia.Jakarta: Pusat Bahasa Departemen Pendidikan nasional.

Denny JA. 2012. "Puisi Esai: Apa dan Mengapa", dalam Jurnal Sajak, nomor 3, Jakarta: PT Jurnal Sajak.

Faruk. 2001. Beyond Imagination: Sastra Mutakhir dan Ideologi. Yogyakarta: Gama Media.

Heryanto, Ariel. 1985. Perdebatan Sastra Kontekstual. Jakarta: PT Rajawali.

Imron, D Zawawi, 2013. "Manusia Gerobak: Catatan Keterpurukan”. pengantar dalam Antologi Puisi Esai Manusia Gerobak. Jakarta: Komodo Book.

Kamandobat, Faisal. "Penyair dan Keruntuhan Sejarah” diterbitkan kompas Desember 2013.

Kristanto, P, 2002, Ekologi Industri, Penerbit ANDI, Yogyakarta.

Rahman, Jamal D, 2013. "Kemungkinan Baru Puisi Esai” pengantar dalam Antologi Puisi Esai Kutunggu Kamu di Cisadane. Jakarta: Komodo Book. 
Rosidi, Ajip. 1977. Laut Biru Langit Biru.Jakarta: Pustaka Jaya.

Swingewood, Alan. 1972. The Sociology of Literature. London: Paladine.

Umar Junus. 1981. Puisi Indonesia dan Melayu Modern. Jakarta: Bhratara Karya Aksara.

Wahid, Abdul. 2000. Sastra Melawan Slogan. Yogyakarta: Sahabat.

Wellek, Rene \& Austin Warren. 1956. Theory of Literature. New York: Horcourt, Brace \& World, Inc. 